\title{
Influence of inerts on explosion limits of hybrid mixtures
}

\author{
J. Serafín \& J. Damec \\ Department of Safety Management, Faculty of Safety Engineering, \\ $V \check{S} B$ - Technical University of Ostrava, Czech Republic
}

\begin{abstract}
Problems of formation of hybrid mixtures are a rather neglected hazard to the manufacturing process. With the origin of such mixtures a necessity of minimizing possible risks that may accompany the formation of hybrid mixtures is connected as well. The article focuses especially on problems of possible inerting hybrid mixtures.

Keywords: inerting, hybrid mixture, prevention.
\end{abstract}

\section{Introduction}

At present, when new substances are used, the formation of a hybrid mixture is not a great problem. The concern is for the moment when the possibility of the formation of hybrid mixture is neglected and thus a hazard resulting from the formation of hybrid mixture is not handled sufficiently.

One of possibilities of preventing large-scale damage that can be caused by the occurrence of hybrid mixture is efficient inerting this mixture.

\section{Definition of basic terms used}

\subsection{Lower explosion limit}

The lower explosion limit (henceforth referred to as LEL) is the lower limit of explosion range. LEL represents such as a value when a shortage of flammable substance in the mixture with an oxidizing agent manifests itself. Here it should be stated that LEL does not depend on a ratio of oxygen to nitrogen in the mixture as stated frequently $[1,2]$. 


\subsection{Hybrid mixture}

The hybrid mixture is a mixture of air and flammable substances of different physical conditions. It should be mentioned here that a small amount of vapour of a flammable liquid or a flammable gas is sufficient for reducing the lower explosion limit of flammable dust-air mixture $[1,2,4]$.

\subsection{Inerting}

Inerting is included in primary explosion protection. In practice this method is increasingly utilized for its efficiency and for maintaining safety. The formation of explosive concentrations is prevented by means of inert substances. What is used in practice for inerting most is gaseous nitrogen. In the course of gas inerting, the space in which the inert is to be used is necessary to be enclosed. Nitrogen is capable of ensuring a rapid increase in minimum initiation energy and a drop in maximum explosion parameters in the system. On the other hand, nitrogen has in comparison with some other inert gases (e.g. carbon dioxide $\mathrm{CO}_{2}$ ) the disadvantage of having the specific thermal capacity almost equal to that of oxygen.

An admixture of inert materials with the higher specific thermal capacity will affect more a change in the lower explosion limit as well as upper explosion limit. This fact is illustrated in fig. 1, where an evident difference between the use of nitrogen and that of carbon dioxide can be seen.

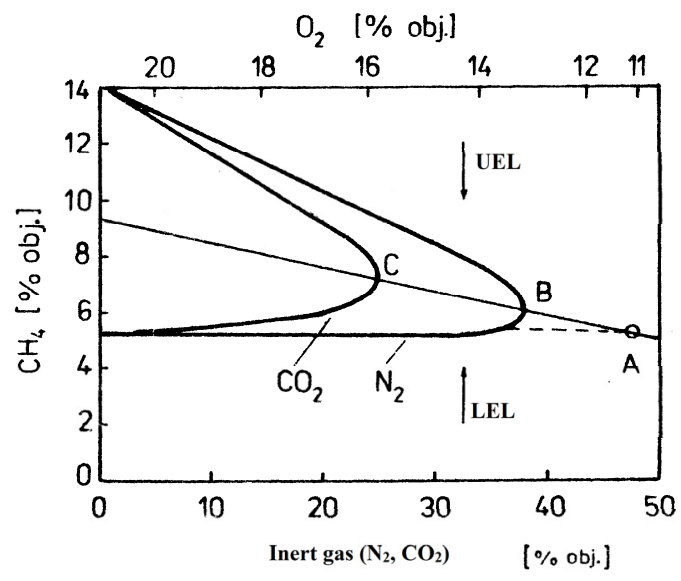

Figure 1: Comparison of influencing LEL and UEL when inert gases $\mathrm{N}_{2}$ and $\mathrm{CO}_{2}$ are used [3].

\section{Experimental determination of LEL of hybrid mixture}

At the Faculty of Safety Engineering, one of the themes of a diploma theses dealt with the verification of possibility of inerting hybrid mixtures. 
Measurement was a part of broader investigation and followed the theme of a bachelor thesis aimed at the determination of a lower explosion limit of a hybrid mixture, namely smooth flour - methane mixture. This mixture had been selected to ensure a possibility of easy repeatability of measurement in the future.

\subsection{Measuring procedure}

The mixture that was used in the experiment was a mixture of smooth flour, methane and air, under conditions of laboratory testing.

As already outlined above, the experiment was based on the measurement that had aimed at the determination of a lower explosion limit of the given hybrid mixture. Results of previous measurement - it is the basis for the determination of influence of inert admixtures on the lower explosion limit of hybrid mixture being studied, are presented in fig. 2 .

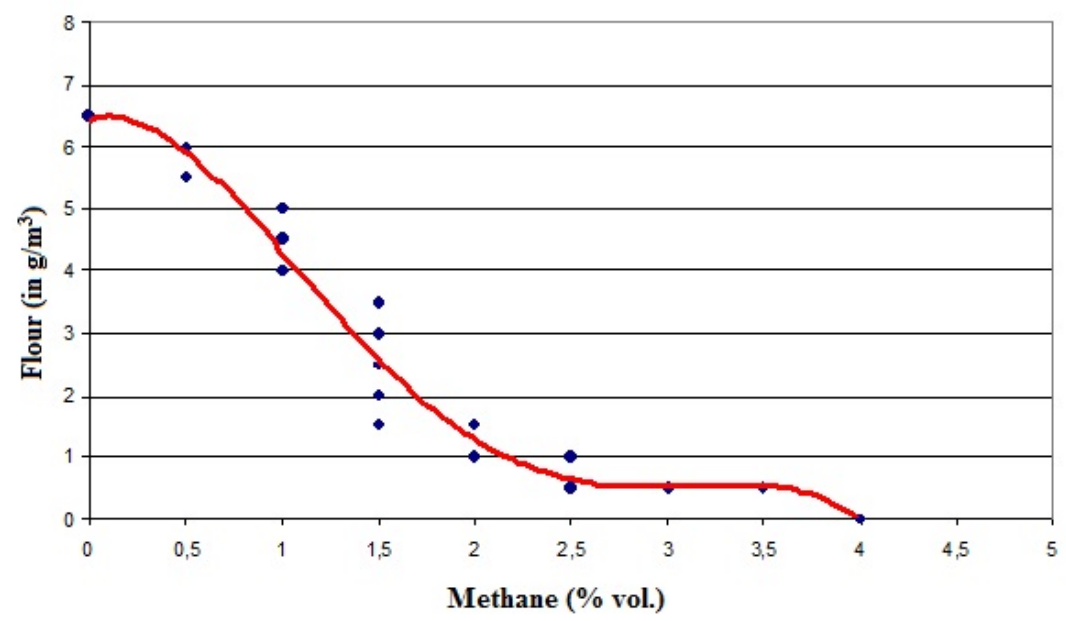

Figure 2: Measured values of dependence of LEL $_{\mathrm{FLOUR}}$ on methane amount.

\subsection{Ground limestone inerting}

The charge, i.e. the required amount of flour will be mixed with the determined amount of limestone in a beaker. This mixture of ground limestone and flour will be evenly poured in four spreading devices in the explosion chamber VK-100 in fig. 3 .

The chamber will be covered with paper foil, and the required amount of methane will be added through the inlet valve, when simultaneously with gas supply the homogenization of the methane - air mixture will be performed by means of a stirrer. After completing the homogenization, the mixture of flour and ground limestone will be raised in the explosion area. The formed hybrid mixture 


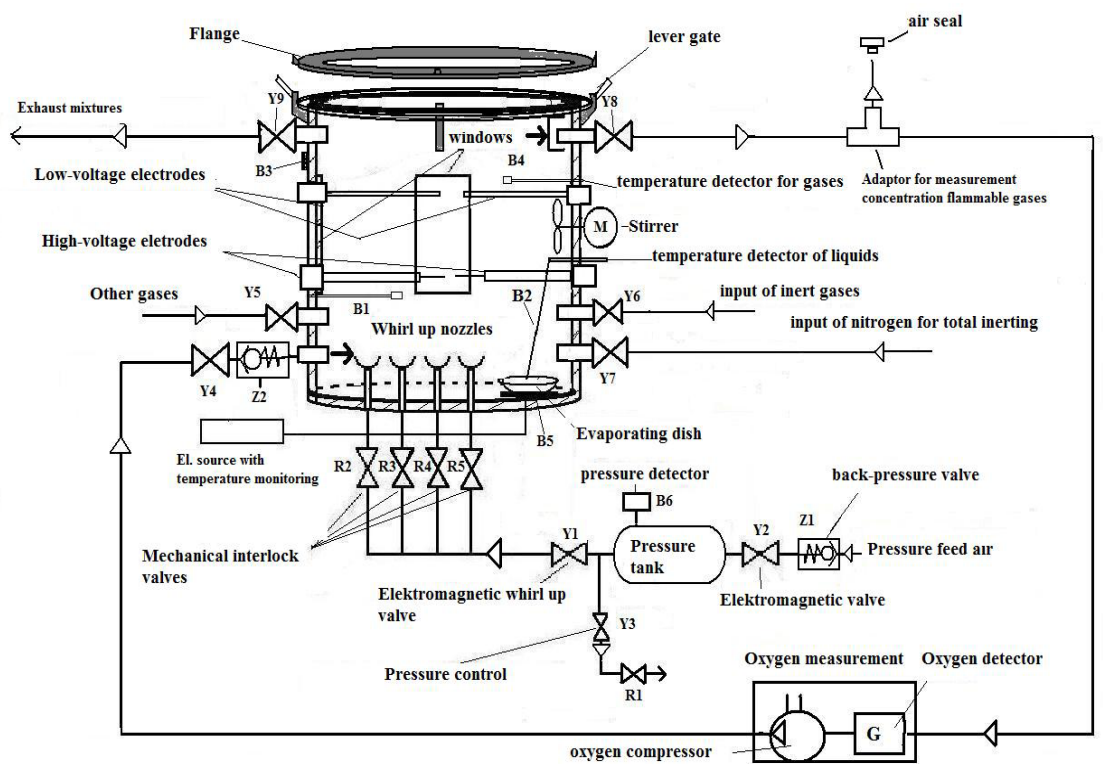

Figure 3: $\quad$ Explosion chamber VK-100.

containing the given amount of inert powder will be subsequently initiated. After each measurement, impurities must be carefully removed from the internal space of the chamber to avoid affecting the next experiments.

At first, the influence of limestone inerting of flour itself without any admixture of methane was examined. Then this was gradually performed for $1 \%$ by volume, for $2 \%$ and for $3 \%$ by volume of methane. The overall result is given in fig. 4, where curves for all methane concentrations being determined are plotted. The raising pressure was 3 bars in all three experiments.

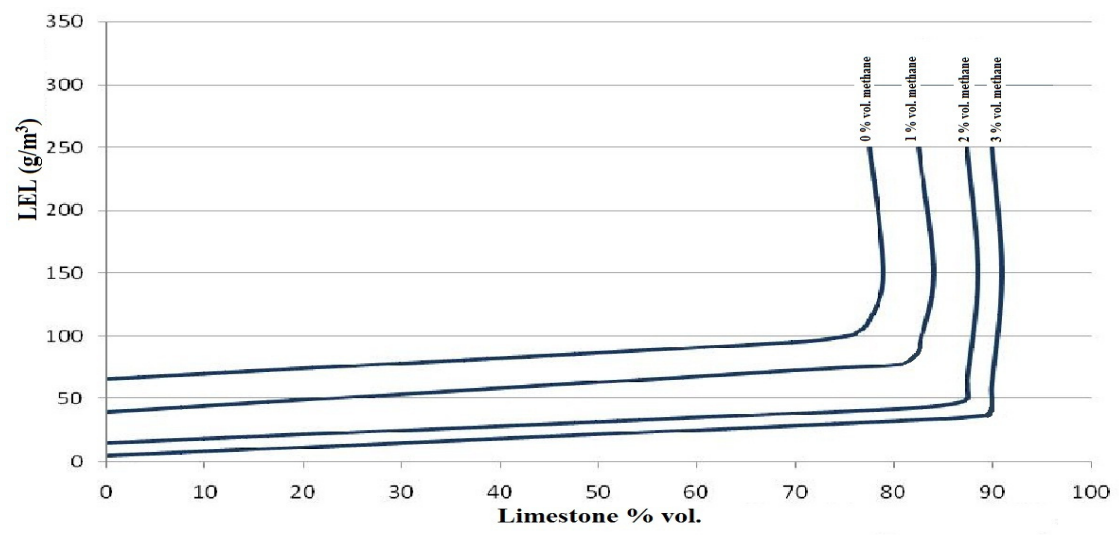

Figure 4: $\quad$ Influence of limestone on LEL of flour - methane hybrid mixture. 


\subsection{Nitrogen inerting}

Another part of the experiment was to measure in the explosion chamber VK100 for the influence of gaseous inert substance on the explosion range of flourmethane - air hybrid mixture. In this case, nitrogen was selected as the inert substance. In practice, nitrogen is the gas that is used for inerting most frequently.

The determined amount of flour will be poured in the spreading dishes in the chamber. On electrodes, nitrocellulose blasting caps will be mounted, and the upper part of explosion area will be covered, likewise in the course of previous measurements, with paper foil. At first, nitrogen stored in a pressure bottle will be supplied to the chamber. In the paper foil, a hole will be produced to enable the determination of concentration of oxygen by an oximeter in the explosion area. After that nitrogen will be put to the space and the chamber fan will be switched on from the control panel to homogenize the mixture. On the oximeter display, the value of volume percentage of oxygen in the chamber will be read. As soon as the required value of oxygen is achieved, the oximeter mouthpiece will be taken from the paper foil and the hole will be sealed with an adhesive strip. The inlet of nitrogen will be closed and the same procedure as with previous measurements will follow. The determined amount of methane will be supplied, flour will be raised and the mixture produced will be initiated. Again, the flame, foil rupture and temperature on the thermometer will be observed.

Measurement was carried out for three different volume amounts of methane in the hybrid mixture $(1 \%, 2 \%$, and $3 \%)$. It is necessary to emphasise that inerting the hybrid mixture with an inert gas had not been measured in the explosion chamber VK-100 yet and measured results are thus of experimental character. The output of this measurement is the following overall graph illustrating the explosion ranges (Figure 5).

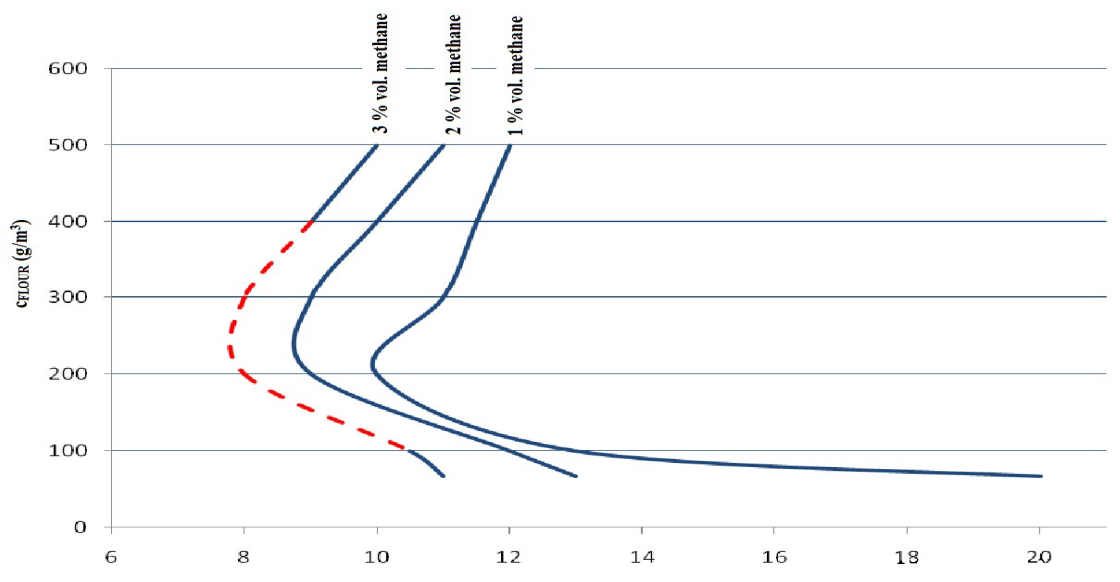

Figure 5: Influence of nitrogen on LEL of flour - methane hybrid mixture. 
In the course of measuring the hybrid mixture with 3 volume per cent of methane, at the concentration $>8.5 \%$ by volume of oxygen in the mixture, a problem appeared; the initiation of the nitrocellulose blasting cap failed and thus the sufficient initiation energy as in all previous cases of measurement was not generated. The cause could be the amount of oxygen being too small to cause the ignition of nitrocellulose. For this reason, these values of the mass concentration of flour ranging from 200 to $300 \mathrm{~g} . \mathrm{m}^{-3}$ cannot be taken as experimentally correct. In fig. 5, the full line represents values really measured in the explosion chamber; the broken line represents expected values on the basis of analogy with the values of both previous measurements with $1 \%$ and $2 \%$ by volume of methane in case of successful initiation of the mixture.

\section{Conclusion}

Problems of hybrid mixtures are an ever topical subject. Thus it is clear that if hybrid mixtures will be formed, it will also be necessary to be concerned with them, to study their properties and possibilities of how to minimize potential consequences brought with such a mixture as efficiently as possible.

\section{References}

[1] DAMEC, J. Protivýbuchová prevence. 1.vyd. Ostrava: Sdružení požárního a bezpečnostního inženýrství, 1998, 188 pp. ISBN 80-86111-21-0

[2] BARTLOVÁ I., DAMEC J. Prevence technologických zařízení., Edice SPBI Spektrum, vol. 30, Ostrava, 243 pp. 2002.ISBN: 80-86634-10-8

[3] NOVOTNÝ M..: Bezpečnostní inženýrství I. - Výbuchy hořlavých plynů a prachi̊. 1. Edition. Pardubice: Ediční středisko VŠCHT, 101 pp., 1988.

[4] SERAFÍN, J., DAMEC, J., DOBEŠ, P., ŠIMANDL, L.: Experimentální stanovení spodní meze výbušnosti hybridní směsi par xylenu, textilních vláken a vzduchu., Sborník mezinárodní konference Požární ochrana 2007, VŠB-TU Ostrava, 2007, s. 532-541, ISBN 978-80-7385-009-8 